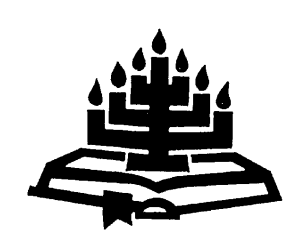

\title{
Philosophical theories of truth and the logical status of intra-Biblical fallacies of contextomy
}

\author{
J.W. Gericke \\ Faculty of Humanities, \\ North-West University \\ Vaal Triangle Campus \\ VANDERBIJLPARK \\ E-mail: jaco.gericke@nwu.ac.za
}

\begin{abstract}
Philosophical theories of truth and the logical status of intraBiblical fallacies of contextomy

The relationship between the Old Testament and the New Testament is a major problem in the discipline of Biblical theology. From a historical perspective the ways in which some New Testament authors have justified their truth-claims by appealing to the Old Testament clearly involve the fallacy of contextomy. A good example of this is the interpretation of texts from the Psalter in the letter to the Hebrews. As a result, the question of logical status arises, i.e., Is it true? With this article the author hopes to contribute to the ongoing discussion by suggesting that, given so many incommensurable philosophical theories on the nature of truth, a more nuanced manner of speaking may be in order. Whether and in what sense the text will be seen as "true" ultimately depends on what we mean when we affirm or deny that something is true in the first place.
\end{abstract}

\section{Opsomming}

Waarheidsteorieë in die filosofie en die logiese status van intra-Bybelse kontekstonomie

Die verhouding tussen die Ou en Nuwe Testamente word tradisioneel beskou as 'n fundamentele probleem in die Bybelse teologie. Vanuit 'n historiese perspektief blyk dit dat party Bybelse outeurs se waarheidsaansprake geregverdig word by wyse van kontekstomieë. 'n Goeie voorbeeld hiervan is die interpretasie van tekste uit die Psalms in die brief aan die Hebreërs. Gevolglik ontstaan 'n vraag na logiese status, met ander 
woorde, Is dit waar? Met hierdie artikel hoop die outeur om 'n bydra te lewer tot die voortgaande bespreking deur voor te stel dat, gegewe die magdom onversoenbare filosofiese teorieë oor die aard van waarheid, dit dalk nodig mag wees om in gesprekke oor die onderwerp meer genuanseerd met die waarheidsbegrip om te gaan. Op welke wyse die teks as "waar" beskou kan word, sal uiteindelik afhanklik wees van wat ons bedoel indien ons beweer of ontken dat iets in die eerste plek waar is.

\section{Introduction}

In his book, Truth - a history and guide for the perplexed, Armesto (1999:ix-x) provides the following clips of childlike faith - or rather, the lack thereof:

Most western parents feel guilty about Santa Claus. When the time comes to face the question whether Santa really exists, they feel like slayers of children's innocence or exploiters of their credulity, or both. In cultures without Santa, other mythical gift bearers generate similar family crises. One mother I know cheerfully admitted that the whole story was hokum and forfeited her children's trust for the rest of her life. A father of my acquaintance tried to stress the poetic truth of the tale and faced an embarrassing interrogation about his hocus-pocus with the Santa suits, Christmas stockings and half-eaten mince pies. Another said, 'It's true about Santa the way it is true in the book that Long John Silver was a pirate.' 'So, it's not true,' his little boy replied. An academic couple, after discussing it thoroughly between themselves, decided to tell their children, 'It's true that Santa brings you your presents in the same way we speak of the wind hurrying or the sun smiling.' The little boy and girl who concluded that the sun and wind exist and that Santa does not, never forgave them for this evasion. A schoolmaster who taught my own children and had a very pious little girl tried saying that the Santa story was a parable: 'You don't suppose,' he said, 'that the things Jesus told in the parables actually happened, do you?' The child ceased to be pious.

Whatever else we may take from this humorous excerpt, the fact is that on a daily basis we all pass judgments on whether the ideas, beliefs and claims we encounter are true or not. In doing so we tend to take the meaning of the concept of truth for granted - we know what it is (or think we do). Philosophers, however, particularly those from the analytic tradition, might beg to differ. Bracketing the question of what the truth ultimately may be, they might wish to know what we mean when we assert that a proposition warrants the predi- 
cates "true" or "false" (see Austin, 1979:117-133; Blackburn \& Simmons, 1999; David, 2004a:331-414; Kirkham, 1992; Künne, 2003; Lynch, 2001; Schantz, 2002; Schmitt, 1995; Soames, 1999; Davidson, 1984; 1990:279-328).

\section{The concept of truth in philosophy and Biblical theology}

The concept of truth is currently one of the most disputed topics in philosophy - it remains a controversial issue in many of the subdisciplines, i.e., in metaphysics, epistemology, philosophy of language, logic, philosophy of science, philosophy of religion, philosophy of law, philosophy of mind, and elsewhere. In the related debates, a number of issues recur time and time again. In this regard, Glanzberg (2008) notes that whereas the central concern revolves around the question of what exactly truth is supposed to be to begin with, the question regarding the nature of the phenomenon can be divided into many sub-queries including, inter alia, the following:

- What sort of things can be called true or false?

- Are there different types of truth?

- How about different degrees of truth?

- Can we ever know truth?

- Can our knowledge of truth be verified?

- Does truth change or only interpretations thereof?

- What popular criteria for determining truth are justified?

- Do different languages/cultures understand the concept in the same way?

These questions about the nature of truth are very interesting, unless you find yourself in the context of Biblical theology where a general dislike of all things philosophical is often tangible (cf. Barr, 1999:146-171). The problem of truth tends to be bracketed by Biblical scholars who consider their enterprise descriptive rather than evaluative and historical rather than philosophical. The question is whether these categories are watertight and mutually exclusive. Even if they do not say as much, how Biblical scholars think of the truth of the text clearly comes to the fore when reading between the lines of their writings: it is either considered a given in a naïve-realist sense (fundamentalists, conservative scholars), qualified and rein- 
terpreted along critical-realist lines (mainstream Biblical theologians and critical scholars), or denied outright (non-theistic readings). Given the pluralism in readerly ideologies, a general consensus seems something that will never be reached - hence the reluctance of many to discuss what is understood to be private beliefs and personal opinions (Davies, 1995:21).

\section{Truth and the relation between the Old and New Testaments}

There are several loci within Biblical theology where the issue of truth and truth claims in the text cannot be avoided. One of these concerns the relationship between the Old and the New Testaments. This is one of the central problems in Biblical theology (cf. Hasel, 1986:20; Brueggemann, 1997:715; Barr, 1999:172-188). The fact is that in many New Testament texts, truth claims are being made by the Biblical authors themselves whenever they assert that a text from the Old Testament means something. Often the reference to the Old Testament passage involves a form of proof-texting by way of which a particular Christological belief is supposed to have been justified. In providing an argument and making truth claims about reality, the New Testament rhetoric thereby opens itself to queries regarding the logical status of the religious language.

The familiar problematic is that from a modern historical perspective, the ways in which many New Testament authors made use of texts from the Old Testament might seem to involve neither valid reasoning nor true statements. A classic example of problematic intertextuality is the forty or so appeals to texts from Psalter in the letter to the Hebrews. An in-depth exegetical discussion of each of these quotes and/or allusions is beyond the scope of this article (on which, cf. the bibliographical references in Guthrie, 2003:294). Suffice to note that the past two decades have witnessed an acceleration of research on Hebrews' uses of the Old Testament in particular and four trends seem to have surfaced. According to Guthrie (2003:271294) these are the following:

1. The first trend concerns a movement away from focus on the question of a specific textual form behind Hebrews and a movement to consideration of the author's own minor adjustments in presentation of the text for stylistic and theological purposes. 
2. The second trend in research concerns approaches that read the structure of Hebrews as framed by expositions of key Old Testament texts.

3. The third trend involves explorations into specific exegetical methods used by the author of Hebrews.

4. The fourth, attempts at discerning the author's hermeneutical program.

According to Guthrie (2003:292), all four of these trends assume the use of the Psalter in Hebrews as in some sense problematic from a modern perspective. Translated into philosophical jargon, it would seem that in many of the quotes from the Psalter the author of Hebrews committed what epistemologists and logicians call the fallacy of "contextomy".

\section{The informal-logical fallacy of contextomy}

According to Engel (1994:106-107), contextomy is a logical fallacy and refers to the selective excerpting of words from their original linguistic context in a way that distorts the source's initially intended meaning, a practice commonly referred to as "quoting out of context". The problem here is not the removal of a quote from its original context (as all quotes are) per se, but the quoter's decision to exclude from the excerpt certain nearby phrases or sentences (which become "context" by virtue of the exclusion) that serve to clarify the intentions behind the selected words. The fallacy of quoting out of context is moreover committed only when a contextomy is offered as evidence in an argument. Such fallacious quoting can involve arguments from authority that often quote the authority as a premise. However, it is possible to quote even legitimate authorities out of context so as to misrepresent the expert's opinion, which is a form of misleading appeal to authority (cf. Engel, 1994:106-107). This seems precisely to be the problem attached to the way in which the author of Hebrews quotes from the Psalter.

Of course, the problematic is nothing novel and is part of the larger query regarding the relation between the Old and New Testaments (cf. Clements, 1985:36; Guthrie, 2003:472). Reading in and between the lines of Biblical scholars' assessments of the problem, it would appear as though one or more of the following explanations for the discrepancies between Hebrews and the Psalter are taken for granted as trivialising the matter altogether: 
- The OT-NT wording differs because the author used the LXX as opposed to the MT (or he had access to an unknown Hebrew Vorlage) on which our own translation of the Psalter is based.

- While we might find the interpretation problematic a historical perspective on the author's methodology shows that he often used the so-called Pesher form of exegesis in Christological format, something which in terms of reading strategy would not have struck the implicit readers as hermeneutically illegitimate.

- Sometimes the text from Hebrews differs verbatim from the Psalter's own text but the meaning conveyed is basically the same.

- The author of Hebrews may on one or more occasions have quoted from memory so that one can expect minor verbal discrepancies in the data.

- The author of Hebrews allegedly never meant merely to provide a historical and descriptive commentary on a text in the Psalter but was in fact in the process of constructing his own theology based on a justified reinterpretation of the Psalter's text in the light of his own understanding of the Christ-event.

- As religious texts the meaning of a verse in the Psalter is not exhausted by a historical and purely descriptive reading and in reception-history the notion of multiple sense, indeterminate reference, double fulfilment, et cetera is considered warranted.

In all of these explanations, the leading assumption is that the problem concerns the alleged presence or absence of theological truth (cf. Ord \& Coote, 1994; Carroll, 1997). Either the epistle is telling the truth about what the Psalter said or not. If this is true then clearly the phenomenon of intertextuality therefore cannot be divorced from philosophical scrutiny via logical assessments as to the supposed validity of the reasoning in the exegetical justification process. In short, philosophical problems and historical inquiries are not mutually exclusive. Yet if the arguments of Biblical authors are to be analysed, it should be remembered that validity and truth are two different things - the former concerns the structure of arguments and an argument can be valid yet untrue (or vice-versa) (cf. LePore, 2000:12)

\section{The meaning of truth}

What is truth, or rather, what do we mean when we affirm or deny that the New Testament author is telling the "truth" about the Old 
Testament text? For it is all fine and well to be making claims regarding the logical status of the New Testament readings, yet if we are not clear in what we mean by the concept of truth - or if we assume different meanings when discussing the matter - the whole issue is bound to lead to misunderstandings which in turn might generate both pseudo-problems and pseudo-solutions. So if validity concerns the structure of arguments, what does truth itself concern? Unless we specify and clarify our own answers with regard to a number of philosophical questions, the future debate on the relation between the Testaments with reference to the problem of intrabiblical interpretation is bound to get out of hand. These questions are, inter alia, the following:

- Is truth/falsehood an appropriate category for the OT/NT relation?

- What type of truth are we supposed to be dealing with here?

- Are there assumed to be degrees of truth involved?

- Can we ever know whether the text relates the truth?

- Can our knowledge of any such related truth be verified?

- Does alleged Biblical truths change or only our interpretations thereof?

- What popular criteria for determining Biblical truth are justified?

- Should different ages and audiences understand the concept similarly?

In the remainder of this article I wish to argue that in response to the question of what truth is assumed to be in the context of predicating the logical status of the religious language of intracanonical forms of intertextuality, it might be prudent if the Biblical scholar makes liberal use of the analytic philosopher's comeback, "It depends on what you mean by "truth". If it seems impossible to settle the matter to the satisfaction of everyone, the next-best thing might be to become aware of the different perspectives available on the concept of truth, which in turn might assist us in appreciating the nuanced and complex nature of the question of whether or not the text is in fact "true". This will allow us to clarify what we mean when we affirm or deny that the property of truthfulness is being instantiated. 


\section{Philosophical theories of truth}

In this article, a variety of philosophical theories of truth will be discussed and it will be shown what it involves to subscribe to each particular theory in the context of the question of whether the interpretation of the Psalter in Hebrews is the truth. However, as far as it is possible, in involving a descriptive philosophical overview, this article will not itself assume the truth (in any sense) or falsity (in any sense) of either the Biblical text, or any specific interpretation by exegetes, or of any particular philosophical theory of truth. Bracketing all three of these contentious matters, the aim is to show what it might involve to entertain or adopt a particular set of philosophical assumptions about the nature of truth; and that in doing so implies the way in which we approach the question of truth with reference to psalm interpretation in Hebrews. In this regard, it is popular to distinguish two kinds of truth-theories, i.e. substantive theories and deflationist theories. The different views on truth will be discussed under these headings for the sake of clarity.

\subsection{Substantive theories}

In this category we find theories that specify the substantive characteristics possessed by all and only truths. The aim of these approaches is therefore to indicate what all truth statements share as being the essential, necessary and sufficient property for truthclaims. While a substantial number of theories are sometimes included in this category (including constructivist, consensus and pluralist theories of truth), spatial limitations incumbent on this article require limiting the discussion to three major perspectives, i.e. the correspondence, coherence and pragmatic theories of truth.

\subsubsection{Correspondence theories}

The correspondence theory is the "default" theory of truth. This theo$r y$ is the one most people think of as obvious and it has generated a lot of philosophical dispute (David, 2004b:43-48; Vision, 2004). According to the correspondence theory, a claim is true if it corresponds to how things are (the "facts" or "reality"), and false if it does not correspond to the way things are. An example of applying this theory to the Hebrews-Psalter (from now on referred to as $\mathrm{H}$ and $\mathrm{P}$ ), relation would be to say the proposition $x$ (where $x$ is any interpretation) in $\mathrm{H}$ about $y$ (where $y$ is the quoted or alluded verse) in $\mathrm{P}$ is true if and only if the reference of $x$ in $\mathrm{H}$ corresponds to the reference of $y$ in $P$. 
From a philosophical perspective, of course, the correspondence theory of truth is not without problems and neither is its application to the H-P-relation. The first problem pertains to the naïve hermeneutical realism of the theory, e.g. consider the idea of the meaning of $x$ or $y$ in $\mathrm{H}$ and $\mathrm{P}$ respectively. Before we decided whether $x$ and $y$ correspond in terms of reference, how do we know our interpretation of $x\left(x_{\mathrm{i}}\right)$ corresponds to $x$ as intended by the author of $\mathrm{H}$ $\left(x_{H}\right)$ ? Moreover, how do we know our interpretation of $y\left(y_{i}\right)$ corresponds to $y$ as intended by the author of $P\left(y_{P}\right)$ ? After all, we can never compare $x$ with $x_{H}$ or $y_{i}$ with $y_{P}-$ i.e., we can never compare our interpretation of the text (the text as it appears) with the text's own meaning (the text in itself). As soon as we attempt to make such a comparison, what is seen as the text itself is once more available to us only as an interpretation of the text. The interpretative spiral involves infinite regress for verification (cf. Cupitt, 1990:111).

A second problem that arises concerns the question of what has to correspond for us to be able to answer the question of truth affirmatively. Is the correspondence to be demonstrated limited to verbal or semantic isomorphisms between $x$ and $y$ in $\mathrm{H}$ and $\mathrm{P}$ respectively? Or should $y$ in $\mathrm{P}$ and $x$ in $\mathrm{H}$ themselves also correspond to actual reality (some extra-textual state of affairs, whatever that is). Even if $x$ $=y$ in theory both might have no correspondence whatsoever to any extratextual state of affairs, meaning that even if $x$ in $\mathrm{H}$ tells the truth about $y$ in $\mathrm{P}$, either $x$ in $\mathrm{H}$ or $y$ in $\mathrm{P}$ (or both) might not have any extratextual world in which they are instantiated. This would imply that $x$ in $\mathrm{H}$ may be true with reference to $y$ in $\mathrm{P}$, yet still false with reference to what is actually the case in the extratextual world about which $\mathrm{H}$ and $\mathrm{P}$ are presumably making claims about. But the problem is bigger: the first problem discussed above again comes to the fore in as much as the supposed extratextual state of affairs that we have any consciousness of would again be little more than our interpretation of it. Therefore one only ends up comparing interprettations of texts with interpretations of other texts; and extratextual realities, meaning at best correspondence of interpretations, might be demonstrated without ever being able to show that the interpretations themselves correspond to what is being interpreted in the first place.

\subsubsection{Coherence theories}

According to the stereotypical version of coherence theories of truth, a statement is true if it is logically consistent with other beliefs that are held (known) to be true (Thagard, 2007:26-47; Young, 2001:89101). Since a belief is assumed to be false if it is inconsistent with 
(contradicts) other beliefs that are believed to be true, we are advised to doubt claims that are inconsistent with the rest of our presumably true beliefs. In general, the coherence theory therefore sees truth as coherence between some specified sets of sentences, propositions or beliefs - truth is said to require a proper fit of elements within the whole belief system.

According to the stereotypical version of this theory, $\mathrm{x}$ in $\mathrm{H}$ is true if and only if it logically coheres with other propositions in the belief system. Of course, one problem emerging from such a formulation concerns the system itself - what is it and what are its boundaries? Is the belief system we are talking about the set of beliefs in the Book of Hebrews, the set of beliefs in the mind of the author, the set of beliefs in the mind of the reader, the set of beliefs in the specific Psalm quoted, or what? All of these might be contested. Unless we can specify the belief-set, how can we either determine the truth of the text or assess truth claims about it?

A second problem with a coherency view is that a belief can be consistent with all our other personal or popularly accepted beliefs and yet have no independent supporting evidence. For example, many metaphysical beliefs are consistent with all imaginable states of affairs (e.g., "the universe came into existence five minutes ago complete with historical records and memories"). The problem for a coherence theory of truth, then, is not only to identify the belief set in question but also the fact that such specification and the resulting possession of a coherent system simply means the absence of inconsistencies, not necessarily of falsities. If it is true that a system can be coherent and false, coherency cannot be a standard criterion for ascertaining actual truthfulness.

\subsubsection{Pragmatic theories}

Pragmatic theories of truth are those accounts, definitions, and perspectives on the concept truth typified by the philosophies of pragmatism and pragmaticism (e.g. Rorty, 1979; Schantz, 2002). They can be said to involve a combination of correspondence and coherency theories yet differ radically with regard to what the representation-reality-relation is all about. Basically, according to the pragmatic theory, a statement is true if it allows you to interact effectively and efficiently with the reality you are dealing with. The less true a belief is, the less it facilitates such interaction. A belief is false if it facilitates no interaction. If more than one belief makes allowance for interaction with the world then both are "true" (i.e. both "work"). In the context of Hebrews' interpretation of the Psalter, proponents of 
this theory might consider the New Testament text to be the truth if it "worked".

The first problem is similar to the one discussed with reference to the coherence and correspondence theories. In asking whether H's interpretation $x$ of $y$ in $P$ is true, what are we in fact asking and what is supposed to work for whom in relation to what else? Is it H's beliefs in $x$ about $y$ in $\mathrm{P}$ for his own religious purposes?; or H's beliefs in $x$ about $y$ in $\mathrm{P}$ for the author of $y$ in P?; H's beliefs in $x$ about $y$ in $\mathrm{P}$ for us?; our own beliefs about $y$ in $\mathrm{P}$ for us?; or even our own beliefs about $x$ in $\mathrm{H}$ for us?; and what if H's reading $x$ of $y$ in $\mathrm{P}$ does work for $\mathrm{H}$ but not for $\mathrm{P}$ or us (or vice versa)? Can $x$ in $\mathrm{H}$ be both true and false at the same time?

Another problem arises even if we limit pragmatics to the author of Hebrews himself. An example here would be the author of H's belief $x$ that the text $y$ in $\mathrm{P}$ is referring to Jesus. According to this theory, $H$ 's claim in $x$ that $P$ in $y$ says $x$ is true if it makes H's life-world (Umwelt) more predictable and thus easier to live in. Of course, the problem is that sometimes false beliefs "work", yet are discovered not to be true even though it might be convenient to believe them. $\mathrm{H}$ might believe something about Christ and enlist words from $y$ in $P$ for Scriptural support - and even if the reading works for $\mathrm{H}$ and just so happens also to be the meaning intended by $\mathrm{P}$, the mere argument that because $y$ is useful for $\mathrm{H}$ it must be identical to $y$ in $\mathrm{P}$ is still a fallacy. In this case the argument would be true but invalid.

\subsection{Deflationary theories}

This is the second cluster or group of truth theories vis-à-vis the substantive one discussed thus far. However, in as much as they are not as central as those already dealt with above, I shall only briefly deal with each in turn. All of them hold in common that the predicate true is an expressive convenience, not the name of a property requiring deep analysis (on the theory, cf. Armour-Garb \& Beall, 2005; McGrath, 2001) Once we have identified the truth predicate's formal features and utility, deflationists argue, we have said all there is to be said about truth. The various deflationary theories tend to be mostly concerned with technical semantic and formal logical issues so the claims may seem unnecessary pedantic to some. Moreover, they come in many varieties, most of which overlap to a considerable extent so that the differences between the various forms of deflationism are often more a matter of nuance than of substance. In this regard, a number of deflationist approaches, among others, may be mentioned. 


\subsubsection{The redundancy/disquotational theory}

According to this view, asserting that a statement $\mathrm{x}$ in $\mathrm{H}$ is true is completely equivalent to asserting the statement itself (on which, cf. Field, 1994:405-452). According to this view, truth is a mere word that is conventional to use in certain contexts of discourse, but not a word pointing to anything in reality. The use of words like fact and truth was nothing but a roundabout way of asserting a proposition so that treating these words as separate problems in isolation from judgment was merely a "linguistic muddle", though there remains some debate as to the correct interpretation of this position. Hence, this particular version of deflationism is commonly referred to as the redundancy theory.

Most predicates attribute properties to their subjects, but the redundancy theory denies that the predicate is true does so. Instead, it treats the predicate is true as empty, adding nothing to an assertion except to convert its meaning to its use. That is, the predicate "... is true" in "H says $x$ " merely asserts the proposition contained in the sentential clause ( $H$ says $x$ ) to which it is applied but does not ascribe any additional property to that proposition or sentence. A variant of redundancy theory is the disquotational theory which uses a modified form of Tarski's schema (cf. Tarski, 1956): to say that " $\mathrm{H}$ is true" is simply to assert $\mathrm{H}$ says $x$.

\subsubsection{The performative theory}

This theory of Strawson is a deflationary theory that is not a redundancy theory (cf. Kirkham, 1992). It involves the claim that ascribing truth to a proposition $x$ in $\mathrm{H}$ is not really characterising the proposition itself, nor is it saying something redundant. Rather, it is telling us something about the reader's intentions. The reader - through his/her agreeing with it, endorsing it, praising it, accepting it, or perhaps conceding it - is licensing our adoption of (the belief in) the proposition. Instead of saying, "What $\mathrm{H}$ says in $x$ is true", one could substitute "I embrace the claim $\mathrm{H}$ makes in $x$ ". The key idea is that saying of some proposition, $x$ in $\mathrm{H}$, that it is true, is to say in a disguised fashion "I commend $x$ to you", or "I endorse $x$ ", or something like that.

\subsubsection{The prosentential (redundancy) theory}

This viewpoint of theory on our subject suggests that the grammatical predicate "is true" does not function semantically or logically as a predicate (cf. Grover, 1992). All uses of "is true" are prosentential uses, i.e. they are substitutes affirming that something was said. 
When someone asserts "What $H$ says in $x$ is true", the person is asking the hearer to consider the sentence " $\mathrm{H}$ says $X$ " and in saying "That is true" is simply affirmation of and substitution for the sentence "H said $X$ ".

\subsubsection{The minimalist theory}

This deflationary approach takes the primary truth-bearing entities to be propositions, rather than sentences (on which, cf. Horwich, 1998). According to the minimalist view, truth is indeed a property of propositions (or sentences, as the case may be) but it is so minimal and anomalous a property that it cannot be said to provide us with any useful information about or insight into the nature of truth. It is fundamentally nothing more than a sort of metalinguistic property. Another way of formulating the minimalist thesis is to assert that the conjunction of all of the instances of the following schema: The proposition that $H(x)$ is true if and only if $x$ provides an implicit definition of the property of truth. Each such instance is an axiom of the theory and there are an infinite number of such instances (one for every actual or possible proposition in the universe). Our concept of truth consists of nothing more than a disposition to assent to all of the instances of the above schema when we encounter them.

\subsubsection{Problems with deflationary perspectives}

Our concern to this point has been only with what deflationary theories involve. In the remainder of this section, I have adapted five of many possible objections from Stoljar and Damnjanovic (2008) that might be forthcoming were we to adopt a deflationist perspective in response to our initial question on the truth of Hebrews in its interpretation of the Psalter.

- Above we saw that deflationism can be presented in either a sententialist version or a propositionalist version. Some philosophers have suggested, however, that the choice between these two versions constitutes a dilemma for deflationism. The objection is that if deflationism about the truth-status of $x$ in $\mathrm{H}$ and about $y$ in $P$ is construed in accordance with propositionalism, then it is trivial; but if it is construed in accordance with sententialism it is false.

- It is often objected that deflationism has particular trouble meeting adequacy conditions. One way to bring out the problem here is by focusing on a particular articulation of the correspondence intuition, an articulation favoured by deflationists themselves. Ac- 
cording to this way of spelling it out, the intuition that a certain sentence or proposition $x$ in $\mathrm{H}$ "corresponds to the facts" about $y$ in $\mathrm{P}$, is the intuition that the sentence or proposition is true because of a certain way the world is; that is, the truth of the proposition is explained by some contingent fact which is usually external to the proposition itself.

- Philosophy of language has isolated a class of propositions that are supposed to fail of truth-value. According to some moral philosophers, for example, moral, interpretative and religious propositions, such as the claim that $x$ in $\mathrm{H}$ is right in interpreting $y$ in $\mathrm{P}$, are neither true nor false. This view finds a gap in the class of propositions between those that are true and those that are false. The deflationary theory of truth is inconsistent with there being a gap in the class of propositions, and this has been thought by many to be an objection to the theory.

- It is commonly said that the beliefs of $\mathrm{H}$ and his assertions aim at truth. The idea here, of course, is not that H's beliefs and assertions are always true in a statistical sense, or even that they are mostly true. The idea is rather that truth is a norm of assertion. This fact about assertion and truth has often been seen to suggest that deflationism must be false. However, the felt contradiction between normativity and deflationism is difficult to specify.

- The final objection begins by drawing attention to a little known doctrine about truth that Moore held at the beginning of the century (masterfully formulated in his so-called "Open-Question argument" with reference to the impossibility of defining the primitive and simple concepts such as good without begging the question). By analogy, no matter what definition one might put forward for truth with reference to H's view expressed in $x$ about the meaning of $y$ in $\mathrm{P}$, it is always possible to ask, "but is that true?".

\section{Conclusion}

This article demonstrates that asking whether the interpretation of the Old Testament in the New (e.g. the Psalter in Hebrews) is "true" from a philosophical perspective is far more complicated than populist notions of truth in the Biblical-theological debate seem to suggest. Hence it might be prudent if we as Biblical theologians take to heart the complexity of the philosophical problematic in our attempt to deal with the question of whether the intertextual relation in 
intracanonical interpretation instantiates the property of truthfulness, or not. We can do this by spelling out from the start what we mean by the concept of truth in our claims regarding the logical status of the Biblical discourse and by motivating our choice of any particular theory on the nature of truth as philosophical-logical concept. Unless we take the time to do so, chances are that future discussions on the subject are bound to involve equivocation of the kind most of us can do without.

\section{List of references}

ARMESTO, F.F. 1999. Truth - a history and guide for the perplexed. New edition. London: Bantam.

ARMOUR-GARB, B. \& BEALL, J.C., eds. 2005. Deflationary truth. Chicago: Open Court.

AUSTIN, J.L. 1979. Truth. Reprinted in Philosophical Papers. 3rd ed. Oxford: Oxford University Press.

BARR, J. 1999. The concept of Biblical theology: an Old Testament perspective. Philadelphia: Fortress.

BLACKBURN, S. \& SIMMONS, K., eds. 1999. Truth. Oxford: Oxford University Press.

BRUEGGEMANN, W. 1997. Theology of the Old Testament: testimony, dispute, advocacy. Philadelphia: Fortress.

CARROLL, R.P. 1997. Wolf in the sheepfold: the Bible as problematic for theology. London: SCM.

CLEMENTS, R.E. 1985. The use of the Old Testament in Hebrews. South Western journal of theology, 28:36-45.

CUPITT, D. 1990. What's a story? London: SCM.

DAVID, S.M. 2004a. Theories of truth. (In Niiniluoto, I., Sintonen, M. \& Wolenski, J., eds. Handbook of epistemology. Dordrecht: Kluwer Academic Publishers. p. 331-414.)

DAVID, S.M. 2004b. Don't forget about the correspondence theory of truth. (In Jackson, F. \& Priest, G., eds. Lewisian themes: the philosophy of David K. Lewis. Oxford: Clarendon. p. 43-48.)

DAVIDSON, D. 1984. Inquiries into truth and interpretation. Oxford: Oxford University Press.

DAVIDSON, D. 1990. The structure and content of truth. The journal of philosophy, 87:279-328.

DAVIES, P.R. 1995. Whose Bible is it anyway? Sheffield: Sheffield Academic Press. (JSOT Sup. Series.)

ENGEL, M.S. With good reason: an introduction to informal fallacies. Bedford: St. Martins.

FIELD, H. 1994. Disquotational truth and factually defective discourse. Philosophical review, 103(3):405-52.

GLANZBERG, M. 2008. Truth. (In Zalta, E.N., ed. The Stanford Encyclopedia of Philosophy.) http://plato.stanford.edu/archives/win2008/entries/truth/ Date of access: 17 Feb. 2009.

GROVER, S. 1992. A prosentential theory of truth. Princeton: Princeton University Press. 
GUTHRIE, G.H. 2003. Hebrews' use of the Old Testament: recent trends in research. Currents in Biblical research, 1(2):271-294.

HASEL, G. 1986. Old Testament theology: basic issues in the current debate. Grand Rapids: Eerdmans.

HORWICH, P. 1998. Truth. 2nd ed. Oxford: Blackwell.

KIRKHAM, R.L. 1992. Theories of truth: a critical introduction. Cambridge: MIT.

KÜNNE, W. 2003. Conceptions of truth. Oxford: Clarendon.

LEPORE, E. 2000. Meaning and argument: an introduction to logic through language. London: Blackwell.

LYNCH, M.P. 2001. The nature of truth: from the classic to the contemporary. Cambridge: MIT.

MCGRATH, M. 2001. Between deflationism and correspondence. New York: Garland.

ORD, D.R. \& COOTE, R.B. 1994. Is the Bible true? Understanding the Bible today. New York: Orbis.

RORTY, R, 1979. Philosophy and the mirror of nature. Princeton: Princeton University Press.

SCHANTZ, R., ed. 2002. What is truth? Berlin: De Gruyter.

SCHMITT, F.F. 1995. Truth: a primer. Boulder: Westview.

SOAMES, S. 1999. Understanding truth. Oxford: Oxford University Press.

STOLJAR, D. \& DAMNJANOVIC, N. 2008. The deflationary theory of truth. (In Zalta, E.N., ed. The Stanford Encyclopedia of Philosophy.) http://plato.stanford.edu/archives/fall2008/entries/truth-deflationary Date of access: 17 Feb. 2007.

TARSKI, A. 1956. The concept of truth in formalized languages: logic, semantics, metamathematics. New York: Clarendon.

THAGARD, F. 2007. Coherence, truth and the development of scientific knowledge. Philosophy of science, 74:26-47.

VISION, G. 2004. Veritas: the correspondence theory and its critics. Cambridge: MIT.

YOUNG, J.O. 2001. A defense of the coherence theory of truth. The journal of philosophical research, 26:89-101.

\section{Key concepts:}

contextomy, fallacy of

philosophical theories of truth

relation: Old and New Testaments

\section{Kernbegrippe:}

filosofiese waarheidsteorieë

kontekstomie, drogargument van

verhouding: Ou en Nuwe Testament 